\title{
Tindak Tutur Guru dan Siswa dalam Pembelajaran Bahasa Indonesia
}

\section{Nelvia Susmita}

Sekolah Tinggi Keguruan dan Ilmu Pendidikan Muhammadiyah Sungai Penuh

Article Info:

Accepted : Mei 2019

Published Online: Juli 2019

\begin{abstract}
Abtract
This research aims to describe the speech act of locussion, illocussion, and perlocussion in Bahasa Indonesia subject for students grade X SMAN 8 Kerinci. Speech act is a crucial aspect which is used in the teaching and learning process in the classroom. Therefore, it is important to concern the use of speech act done by both teachers and the students in order to accomplish the learning goals. The theories used to analize the speech act of the teachers and students in the learning process of Bahasa Indonesia subject in this research are proposed by Nadar (2008), Suadi (2014), Chaer (2010), Bonodari (20115), and Rehardi (2005). The type of this research is qualitative research. The subject of the research are teachers and students grade X in SMaN 8 Kerinci in the process of teaching and learning in Bahasa Indonesia subject. The technique of data collection are namely listening freely and speaking involved, recording techinque, and writing down technique. The technique of data analysis is equal pragmatics. The result of the research can be described as follow: it is found the speech act in form of locussion, illocussion, and perlocussion. The speech act of locussion includes the forms of news, questions forms and commands forms. The speech act of illocussion includes assertive illocussion, directive, expressive, commisive, and declarative. The speech act of perlocussion that was found is giving influences.
\end{abstract}

Keywords: speech act, learning of bahasa indonesia

This is an open access article distributed under the Creative Commons Attribution License, which permits unrestricted use, distribution, and reproduction in any medium, provided the original work is properly cited. C2019 by author

\section{PENDAHULUAN}

Penggunaan bahasa lisan dalam interaksi belajar mengajar merupakan salah satu bentuk komunikasi yang berlangsung dalam interaksi kelas. Melalui proses komunikasi akan memunculkan peristiwa tutur dan tindak tutur. Peristiwa tutur merupakan proses terjadinya atau berlangsungnya interaksi linguistik dalam suatu bentuk ujaran atau lebih yang melibatkan dua belah pihak, yaitu penutur dan lawan tutur, dengan satu pokok tuturan, di dalam waktu, tempat, dan situasi tertentu. Tindak tutur dalam interaksi belajar mengajar di kelas dapat dimanfaatkan sebagai pengajaran pragmatik. Pragmatik adalah studi yang mempelajari tentang makna yang berhubungan dengan situasi ujar (Leech, 2015: 8). Pragmatik mengkaji makna tuturan yang dikehendaki oleh penutur dan menurut konteksnya. Konteks dalam hal ini berfungsi sebagai dasar pertimbangan dalam mendeskripsikan makna tuturan dalam rangka penggunaan bahasa dalam komunikasi. Salah satu objek kajian pragmatik yaitu tindak tutur.

Salah satu contoh tindak tutur dapat dilihat dalam interaksi adalah antara guru dengan siswa dalam kegiatan pembelajaran yang menggunakan bahasa lisan sebagai alat komunikasi. Dengan berbagai tindak tutur, guru dan siswa melakukan komunikasi bersemuka di dalam pembelajaran. Komunikasi yang terjalin antara guru dan siswa diharapkan dapat menyalurkan ide atau gagasan sehingga dapat dipahami, diterima dan diikuti oleh orang lain selaku lawan tutur.Proses komunikasi yang melibatkan tuturan-tuturan antara guru dengan siswa dan siswa dengan siswa sangat bervariasi, antara lain (a) tindak tutur berdasarkan cara penyampaiannya yakni tindak tutur langsung dan tindak tutur tidak langsung; (b) Tindak tutur berdasarkan pengungkapan makna yakni tindak tutur literal dan tindak tutur tidak literal; (c) tindak tutur lokusi, ilokusi dan perlokusi. Tindak tutur lokusi yaitu tindak yang dilakukan dalam menyatakan sesuatu. Tindak tutur ilokusi yaitu tindak tutur untuk melakukan 
sesuatu sedangkan tindak tutur perlokusi yaitu hasil atau efek yang ditimbulkan oleh ungkapan ujaran itu pada pendengar sesuai dengan situasi dan kondisi ujaran.

Berdasarkan hasil observasi dan wawancara di SMA N 8 Kerinci ditemukan adanya penggunaan bentuk tindak tutur yang digunakan untuk menyampaikan maksud yang diinginkan. Tuturan dari guru yang mengatakan: "Haduh... Ibu sedang berbicara, kelas ini kayak pasar aja" memiliki dua maksud, yakni menginformasikan sebagai makna lokusi, juga menyindir sebagai makna ilokusi. Menyindir yang dimaksud adalah, sindiran guru terhadap siswa karena yang disampaikan guru tidak sama yang dimaksud. Maksud dari tuturan guru bukanlah kelas yang seperti pasar, akan tetapi suasana ruang kelas yang ribut seperti ketika guru sedang menjelaskan. Perlokusi (efek) yang diharapkan adalah siswa segera diam dan memperhatikan guru yang sedang menjelaskan pembelajaran. Sehubungan dengan hal itu, tindak tutur yang dilakukan dalam kegiatan pembelajaran memiliki maksud dan tujuan dari setiap penutur terhadap lawan tutur. Tujuan dan maksud tersebut tidak diungkapkan tidak secara langsung diungkapkan secara jelas terhadap lawan tutur. Tujuan dan maksud diungkapkan melalui implikasi-implikasi yang mengharuskan lawan tutur untuk memahaminya.

Berdasarkan hal tersebut melalui penelitian ini akan dikaji pemakaian tindak tutur dalam pembelajaran Bahasa Indonesia. Penulis memilih tempat penelitian di kelas X SMA Negeri 8 Kerinci karena penulis bermaksud mengetahui secara langsung bagaimana pemakaian tindak tutur dalam pembelajaran bahasa Indonesia sekolah tersebut.Permasalahan yang telah diuraikan tersebut masih terlalu luas sehingga tidak dapat diteliti seluruhnya dalam penelitian ini. Oleh karena itu, pembatasan penelitian ini mencakup bentuk tindak tutur lokusi, ilokusi, dan perlokusi guru dan siswa dalam pembelajaran bahasa Indonesia kelas X SMA Negeri 8 Kerinci. Pada batasan masalah maka rumusan masalah dalam penelitian ini adalah bagaimanakah bentuk-bentuk tindak tutur lokusi, ilokusi, dan perlokusi dalam pembelajaran bahasa Indonesia kelas X SMA Negeri 8 Kerinci? Tujuan penelitian ini untuk mendeskripsikan jenis-jenis tindak tutur lokusi, ilokusi, dan perlokusi guru dan siswa dalam pembelajaran bahasa Indonesia kelas X SMA Negeri 8 Kerinci.

\section{METODE}

Penelitian ini digolongkan ke dalam penelitian kualitatif, sedangkan metode yang digunakan adalah metode deskriptif. Sugiyono (2012:15) menyatakan penelitian kualitatif adalah penelitian yang berlandaskan pada filsafat postpositisme, digunakan untuk meneliti kondisi obyek yang alamiah. Peneliti adalah instrumen kunci, teknik pengumpulan data yang dilakukan untuk memperoleh data dalam penelitian ini adalah metode simak. Dikatakan metode simak karena cara yang digunakan untuk memperoleh data dilakukan dengan cara menyimak penggunaan bahasa. Metode yang digunakan dalam analisis data penelitian ini adalah metode padan. Metode ini adalah metode analisis bahasa yang penentunya tidak menjadi bagian dari bahasa yang bersangkutan (Sudaryanto, 2015: 15). Penggunaan metode ini didasarkan pada asumsi bahasa yang diteliti memiliki hubungan dengan hal-hal yang ada di luar bahasa yang bersangkutan. Hal yang dikaji memiliki kaitan dengan penutur, dan lawan tutur. Metode padan yang digunakan dalam penelitian ini adalah metode padan pragmatik.

Dalam penelitian kualitatif, yang menjadi instrumen atau alat penelitian adalah peneliti itu sendiri. Menurut Sugiyono (2012:306) penelitian kualitatif adalah human instrument yang berfungsi menetapkan fokus penelitian, memilih informan sebagai sumber data, melakukan pengumpulan data, menilai kualitas data, analisis data, menafsirkan data, dan membuat kesimpulan atas temuannya.Teknik pengumpulan data merupakan langkah yang paling strategis dalam penelitian karena tujuan utama dari penelitian adalah memeroleh data. Tanpa mengetahui teknik pengumpulan data, peneliti tidak akan mendapatkan data yang memenuhi standar data yang ditetapkan. Teknik pengumpulan data dalam penelitian ini meliputi observasi (simak), teknik rekam (video), dan catatan lapangan. Pengumpulan data dengan observasi adalah pengamatan dan pencatatan secara sistematis terhadap gejala yang tampak pada objek penelitian. Penelitian menggunakan pengamatan dan pencatatan yang dilakukan terhadap objek di tempat terjadi atau berlangsungnya peristiwa sehingga obsever berada bersama objek yang diteliti.

Penggunaan teknik ini untuk mengetahui bahasa yang digunakan oleh guru dan siswa dalam berkomunikasi pada saat pembelajaran. Setelah ditentukan objek yang diteliti, peneliti melakukan proses rekaman video interaksi guru dan siswa dalam proses pembelajaran secara alami. Alat perekam untuk memperoleh data adalah video digital. Selama pelaksanaan perekaman, peneliti tidak terlibat dalam percakapan.Setelah data terkumpul, selanjutnya dilakukan analisis data. Data-data yang telah terkumpul diidentifikasi dan diklarifikasi. Menurut Moleong (2012:280) langkah-langkah atau proses analisis data secara umum dapat digunakan sebagai berikut.Metode yang digunakan dalam analisis data penelitian ini adalah metode padan. Metode ini adalah metode analisis bahasa yang penentunya tidak menjadi bagian dari bahasa yang bersangkutan (Sudaryanto, 2015: 15). Penggunaan metode ini didasarkan pada asumsi bahasa yang diteliti 
memiliki hubungan dengan hal-hal yang ada di luar bahasa yang bersangkutan. Hal yang dikaji memiliki kaitan dengan penutur, dan lawan tutur. Metode padan yang digunakan dalam penelitian ini adalah metode padan pragmatik.

Langkah-langkah yang dilakukan dalam menganalisis data adalah sebagai berikut: 1) Menyimak dan mencatat semua data alamiah/ujaran spontan siswa dan guru yang muncultermasuk mencatat konteks pada suatu proses percakapan antara guru dan siswa di SMA Negeri 8 Kerinci; 2) Data yang didapat langsung dianalisis dengan menggunakan metode padan dan teknik pilah unsur penentu; 3) Mengklasifikasikan data berdasarkan tindak tutur lokusi, ilokusi, dan perlokusi berserta fungsi tindak tutur; 4) Berdasarkan hasil identifikasi dan klasifikasi data, dilakukan kegiatan penarikansimpulan sementara dengan cara menafsirkan secara utuh dan terpadu seluruh data yang tersedia; 5) Memeriksa/mengecek kembali data yang ada; 6) Penarikan simpulan akhir.

\section{HASIL PENELITIAN}

Bentuk tindak tutur yang ditemukan dalam pembelajaran bahasa Indonesia kelas X SMA Negeri 8 Kerinci meliputi tindak tutur lokusi, ilokusi, dan perlokusi. Dilihat dari bentuk lokusi terdapat bentuk berita, tanya, dan perintah. Dilihat dari tindak tutur ilokusi, ditemukan tindak tutur ilokusi asertif, direktif, ekspresif, komisif dan deklaratif. Dilihat dari tindak tutur perlokusi, dalam penelitian ini ditemukan perlokusi membuat mitra tutur melakukan sesuatu, tertarik, senang dan paham. Untuk lebih jelasnya, bentuk tindak tutur yang ditemukan dalam pembelajaran bahasa Indonesia kelas X SMA Negeri 8 Kerinci dapat dilihat pada tabel 2 berikut.

Tabel 1: Bentuk Tindak Tutur Guru dan Siswa dalam Pembelajaran Bahasa Indonesia Kelas X SMA Negeri 8 Kerinci

\begin{tabular}{|c|c|c|}
\hline No. & Jenis Tindak Tutur & Bentuk Tindak Tutur \\
\hline 1. & Lokusi & Berita \\
\hline & & Tanya \\
\hline & & Perintah \\
\hline \multirow[t]{5}{*}{2.} & Ilokusi & Asertif \\
\hline & & Direktif \\
\hline & & Ekspresif \\
\hline & & Komisif \\
\hline & & Deklaratif \\
\hline 3. & Perlokusi & Memberikan Pengaruh \\
\hline
\end{tabular}

\section{PEMBAHASAN}

Berdasarkan hasil penelitian yang ditemukan dalam proses pembelajaran bahasa Indonesia di SMA Negeri 8 Kerinci, maka penganalisisan sesuai permasalahan-permasalahan yang telah dirumuskan pada rumusan masalah penelitian ini, yakni: mendeskripsikan bentuk tindak tutur lokusi, ilokusi, dan perlokusi guru dan siswa dalam pembelajaran bahasa Indonesia kelas X SMA Negeri 8 Kerinci.

\section{Bentuk Tindak Tutur}

\section{Tindak Tutur Lokusi}

a. Bentuk Berita

Dalam Tata Bahasa Indonesia, bentuk berita pada umumnya digunakan oleh penutur untuk membuat pernyataan sehingga isinya merupakan informasi bagi mitra tuturnya. Bentuk berita sama dengan bentuk pernyataan yakni berfungsi hanya untuk memberitahukan informasi terhadap orang lain (lawan tutur). Lokusi bentuk berita dalam penelitian ini dapat dilihat sebagai berikut.

356) Siswa : "Lihat"

(Siswa : "Lihat")

Tuturan (356) terjadi setelah guru menanyakan kepada siswa apakah bisa melihat tulisan yang ada di papan tulis dan kemudian siswa menjawab "Lihat". Jawaban "Lihat" yang diberikan siswa merupakan tuturan lokusi berita yang bertujuan untuk menyampaikan suatu informasi kepada lawan tutur. Tuturan tersebut dimaksudkan siswa untuk menginformasikan kepada guru bahwa mereka dapat melihat tulisan 
yang ada di papan tulis. Siswa tidak memiliki maksud apa-apa kecuali ingin memberi jawaban terhadap pertanyaan yang diberikan oleh guru.

\section{b. Bentuk Tanya}

Bentuk tanya (pertanyaan) secara formal ditandai oleh kehadiran kata tanya seperti apa, siapa, kapan, dan bagaimana, dengan atau tanpa partikel -kah sebagai penegas. Bentuk tanya biasanya diakhiri dengan tanda tanya diakhir tuturan. Bentuk tanya terdiri dari dua macam, yakni tanya yang hanya memerlukan jawaban ya atau tidak dan tanya yang memerlukan penjelasan dari orang yang ditanya. Lokusi bentuk tanya dalam pembelajaran bahasa Indonesia kelas X SMA Negeri 8 Kerinci dapat dilihat pada contoh berikut.

(355) Guru : "Melihat semua?"

(Guru : “Apakah semuanya bisa melihat?”)

Tuturan (355) terjadi setelah guru menjelaskan pembelajaran kemudian bertanya kepada siswa dengan tuturan "Paham?". Tuturan "Paham?" yang dituturkan oleh guru dimaksudkan untuk menanyakan kepada siswa apakah sudah paham dengan penjelasan yang telah diberikan oleh guru. Penutur tidak memiliki maksud lain selain bertanya kepada siswa, untuk memastikan apakah sudah paham dengan penjelasan yang telah diberikan.

\section{c. Bentuk Perintah}

Bentuk perintah terbagi menjadi bentuk perintah yang sebenarnya. Bentuk perintah memiliki fungsi agar lawan tutur segera melakukan perbuatan yang diperintahkan oleh penutur. Berikut dapat dilihat contoh tindak tutur lokusi bentuk perintah dalam pembelajaran bahasa Indonesia kelas X SMA Negeri 8 Kerinci.

(313) Guru : "Ayo Uus! Yang lain dengarkan!"

(Guru : “Ayo, Uus! Yang lain dengarkan!”)

Tuturan (313) muncul ketika salah satu siswa ingin membaca paragraf deduktif yang telah dibuatkan. Tuturan guru yang mengatakan "Ayo Uus! Yang lain dengarkan!” merupakan tindak tutur lokusi bentuk perintah. Tuturan guru yang mengatakan “Ayo Uus!” merupakan perintah untuk siswa yang bernama Uus untuk segera membacakan paragraf deduktif yang telah dibuatkan. Kemudian guru mengatakan "Yang lain dengarkan!" yang bermakna perintah untuk siswa yang lain untuk mendengarkan apa yang akan dibacakan oleh siswa yang bernama Uus.

\section{Tindak Tutur Ilokusi}

a. Asertif

Tindak tutur asertif merupakan bentuk tutur yang mengikat penutur pada kebenaran proposisi yang diungkapkannya. Tuturan jenis ilokusi asertif ini mendominasi dari keseluruhan jenis ilokusi. Berikut contoh ilokusi asertif yang ditemukan dalam penelitian ini.

(180)Guru : "Nahh ada kalimat utama, dan ada kalimat penjelas itulah paragraf deduktif."

(Guru : "Itulah paragraf deduktif, ada kalimat utama dan

ada kalimat pejelas")

Tuturan pada data (180) terjadi setelah siswa memberikan jawaban atas pertanyaan guru tentang paragraf. Tuturan "Nahh ada kalimat utama, dan ada kalimat penjelas itulah paragraf deduktif." yang dituturkan oleh guru selain memiliki maksud untuk menginformasikan sebagai makna lokusi, juga memiliki maksud mengakui sebagai makna ilokusi. Tuturan mengakui yang dimaksud yaitu pengakuan kesamaan pendapat atas jawaban yang diutarakan oleh siswa tentang kelengkapan paragraf deduktif yang memiliki kalimat utama dan kalimat penjelas.

\section{b. Direktif}

Tindak tutur direktif adalah tuturan yang dimaksudkan untuk menimbulkan beberapa efek melalui tindakan sang penyimak. Tuturan direktif dalam penelitian ini dapat dilihat pada data berikut.

(297)Guru : "Ulang kalimat utamanya saja"

(Guru : "Ulang kalimat utamanya")

Tuturan (297) muncul setelah guru menanyakan kepada siswa tentang kalimat utama pada sebuah paragraf. Tuturan yang dituturkan oleh guru dengan mengatakan "Ulang kalimat utamanya saja", selain berisi tuturan menginformasikan terhadap mitra tutur juga merupakan tuturan berisi suruhan terhadap lawan tutur agar segera mengulang membacakan kalimat utama pada paragraf tersebut. Tuturan "Ulang kalimat utamanya saja" yang dituturkan oleh guru dimaksudkan untuk mempengaruhi lawan tutur agar mau bertindak sesuai yang diinginkan oleh penutur untuk segera mengulang menyampaikan kalimat utama yang ada pada paragraf. 


\section{c. Ekspresif}

Tuturan ilokusi ekspresif adalah tuturan untuk mengekspresikan, mengungkapkan, atau memberitahukan sikap psikologis sang pembicara menuju suatu pernyataan keadaan yang diperkirakan. Berdasarkan penelitian yang dilakukan, ditemukan tindak ilokusi eksprsif sebagai berikut.

(332) Siswa : "Uus Uus, ayo Uus!

(Siswa : “Ayo, Uus!)

Tuturan (332) terjadi setelah guru meminta siswa yang bernama Uus untuk menuliskan contoh paragraf di papan tulis. Tuturan "Uus Uus, ayo Uus!" yang dituturkan oleh siswa selain memiliki maksud menginformasikan sebagai makna lokusi juga memiliki maksud menyemangati sebagai makna ilokusi. Tuturan menyemangati yang dimaksud adalah siswa lain menyemangati siswa yang bernama Uus agar bersemangat pada saat menuliskan contoh paragraf di papan tulis.

\section{d. Komisif}

Tindak tutur ilokusi komisif adalah tindak tutur yang melibatkan pembicara pada beberapa tindakan yang akan datang. Tuturan ilokusi komisif pada penelitian ini dapat dilihat sebagai berikut.

(426) Guru :"Ada pertanyaan lagi untuk materi kita hari ini?"

(Guru: "Apakah ada pertanyaan lagi tentang materi hari

ini?")

Tuturan data (426) terjadi ketika guru selesai menjelaskan materi pembelajaran. Tuturan guru dengan mengatakan "Ada pertanyaan lagi untuk materi kita hari ini?" selain bermaksud menanyakan sebagai makna lokusi juga bermaksud menawarkan sebagai makna ilokusi. Tuturan dengan fungsi menawarkan yang dimaksud adalah tawaran kepada siswa untuk bertanya apabila masih ada yang belum paham dengan materi pembelajaran yang telah diberikan oleh guru. Selain itu tuturan menawarkan "Ada pertanyaan lagi untuk materi kita hari ini?" dituturkan guru sebagai bentuk konfirmasi terhadap pemahaman siswa tentang materi pembelajaran yang telah disampaikan.

\section{e. Deklaratif}

Tindak tutur ilokusi deklaratif adalah tuturan bila performasinya berhasil akan menyebabkan korespondensi yang baik antara proposional dengan realitas. Ilokusi deklaratif dalam penelitian ini dapat dilihat sebagai berikut.

(337) Guru : "Selesai, silahkan duduk dulu Uus!"

(Guru : "Selesai, Uus silahkan duduk dulu!)

Tuturan (337) terjadi pada saat siswa yang bernama Uus selesai menuliskan paragraf deduktif miliknya di papan tulis. Tuturan "Selesai, silahkan duduk dulu Uus!" yang dituturkan oleh guru selain memiliki makna menyuruh sebagai makna lokusi, juga bermakna mengizinkan sebagai makna ilokusi. Tuturan ilokusi deklaratif dengan fungsi mengizinkan yang dimaksud adalah memberikan izin kepada Uus untuk duduk ditempatnya.

\section{Tindak Tutur Perlokusi}

Tindak tutur perlokusi adalah tindak tutur yang memiliki efek atau daya pengaruh yang ditimbulkan dari tuturan penutur terhadap mitra tutur. Berdasarkan penelitian yang dilakukan dalam pembelajaran bahasa Indonesia kelas X SMA Negeri 8 Kerinci ditemukan tindak perlokusi sebagai berikut.

(172) Guru : "Nah seperti itulah paragraf deduktif. Yahh, ada kalimat utama, harus ada kalimat penjelas. Ada kalimat utama, wajib diikuti kalimat penjelas"

(Guru :" Seperti itulah paragraf deduktif. Ada kalimat

utama harus ada kalimat penjelas. Ada kalimat utama wajib diikuti kalimat penjelas")

Tuturan pada data (172) terjadi pada saat guru sedang menjelaskan pembelajaran. Tuturan data (172) selain mengandung lokusi berupa informasi kepada siswa juga mengadung ilokusi menyatakan. Perlokusi pada data (172) adalah siswa menjadi paham dengan apa yang dijelaskan oleh guru.

\section{KESIMPULAN}


Berdasarkan hasil penelitian dan pembahasan yang telah dilakukan dapat diambil kesimpulan, yakni bentuk tindak tutur yang ditemukan dalam pembelajaran bahasa Indonesia kelas X SMA Negeri 8 Kerinci adalah tindak tutur lokusi, ilokusi, dan perlokusi. Tindak tutur lokusi yang ditemukan yaitu lokusi bentuk berita, tanya, dan perintah. Tindak tutur ilokusi yang ditemukan yaitu ilokusi asertif, direktif, ekspresif, dan deklaratif. Sedangkan tindak tutur perlokusi yang ditemukan yaitu memberikan pengaruh.

\section{DAFTAR RUJUKAN}

Achmat, HP dan Alek Abdullah. (2013). Linguistik Umum. Jakarta: Erlangga.

Ahmadi, Rulam. (2014). Metodologi Penelitian Kualitatif. Yogyakarta.

Chaer, Abdul dan Leoni Agustin. (2010). Sosiolinguistik: Perkenalan Awal. Jakarta: Rineka Cipta.

Chaer, Abdul. (2002). Psikolinguistik: Kajian Teoretik. Jakarta: Rineka Cipta.

Cummings, Luise. Pragmatik: Sebuah Perspektif Multidisipliner. Yogyakarta: Pustaka Belajar.

Leech, Geoffrey. (2015). Prinsip-prinsip pragmatik. Terjemahan oleh Oka, M.D.D Universitas Indonesia:

Jakarta.

Mahsun. (2012). Metode Penelitian Bahasa. Jakarta: PT Raja Grafindo Persada.

Moeleong, Lexy J. (2010). Metodologi Penelitian Kualitatif. Bandung: Remaja Rosda Karya.

Nadar, FX. (2009). Pragmatik dan Penelitian Pragmatik. Yogyakarta. Graha Ilmu.

Rahadi, Kunjana. (2002). Pragmatik Kesantunan Imperatif Bahasa Indonesia. Jakarta:Erlangga.

Suandi, I Nengah. (2014). Sosiolinguistik. Yogyakarta: Graha Ilmu.

Sugiyono. (2010). Metode Penelitian Kuantitatif, Kualitatif dan R\&D. Bandung: CV Alfabeta.

Tarigan, Henry Guntur. (2009). Pengajaran Pragmatik. Bandung: Angkasa.

Wijana, I Dewa Putu. (1996). Dasar-dasar Pragmatik. Yogyakarta: Andi. 